\title{
Ovarian Squamous Cell Carcinoma
}

National Cancer Institute

\section{Source}

National Cancer Institute. Ovarian Squamous Cell Carcinoma. NCI Thesaurus. Code C40093.

A usually high grade squamous cell carcinoma that arises from the ovary and is not associated with a germ cell tumor. The prognosis is poor. 